\title{
Effect of estradiol and bisphenol A on human hepatoblastoma cell viability and telomerase activity
}

\author{
B.L. Xu' ${ }^{1}$, Q.Z. Zhao ${ }^{2}$, X.Y. Gao ${ }^{1}$ and G.J. $\mathrm{Hou}^{1}$ \\ ${ }^{1}$ Children's Hospital of Zhengzhou, Zhengzhou, China \\ ${ }^{2}$ Basic Medical College, Zhengzhou University, Zhengzhou, China
}

\begin{abstract}
Sex hormones from environmental and physiological sources might play a major role in the pathogenesis of hepatoblastoma in children. This study investigated the effects of estradiol and bisphenol A on the proliferation and telomerase activity of human hepatoblastoma HepG2 cells. The cells were divided into 6 treatment groups: control, bisphenol A, estradiol, anti-estrogen ICI 182,780 (hereinafter $\mathrm{ICl}$ ), bisphenol $\mathrm{A}+\mathrm{ICl}$, and estradiol $+\mathrm{ICl}$. Cell proliferation was measured based on average absorbance using the Cell Counting- 8 assay. The cell cycle distribution and apoptotic index were determined by flow cytometry. Telomerase activity was detected by polymerase chain reaction and a telomeric repeat amplification protocol assay. A higher cell density was observed in bisphenol $A(P<0.01)$ and estradiol $(P<0.05)$ groups compared with the control group. Cell numbers in $S$ and $G 2 / M$ phases after treatment for $48 \mathrm{~h}$ were higher $(P<0.05)$, while the apoptotic index was lower $(P<0.05)$ and telomerase activities at 48 and $72 \mathrm{~h}(\mathrm{P}<0.05)$ were higher in these groups than in the control group. The cell density was also higher in bisphenol $\mathrm{A}+\mathrm{ICl}$ $(\mathrm{P}<0.01)$ and estradiol $+\mathrm{ICl}(\mathrm{P}<0.05)$ groups compared with the $\mathrm{ICl}$ group. Furthermore, cell numbers were increased in $\mathrm{S}$ and G2/M phases $(P<0.05)$, while the apoptotic index was lower $(P<0.05)$ and telomerase activities at 48 and $72 \mathrm{~h}$ were higher $(\mathrm{P}<0.05)$ in these groups than in the ICl group. Therefore, bisphenol A and estradiol promote HepG2 cell proliferation in vitro by inhibition of apoptosis and stimulation of telomerase activity via an estrogen receptor-dependent pathway.
\end{abstract}

Key words: Estradiol; Bisphenol A; HepG2; Telomerase activity

\section{Introduction}

Hepatoblastoma $(\mathrm{HB})$ is the most common malignant, solid liver tumor in children, arising from multipotent stem cells that differentiate into liver and bile duct epithelial cells in undifferentiated embryonic tissue (1). It accounts for about $25 \%$ of pediatric liver tumors and $50-69 \%$ of malignant hepatic tumors among primary embryonal tumors (2). HB is presumed to be caused by abnormal hyperplasia and differentiation of healthy liver cells, although the details of its pathogenesis remain unknown (3).

It has been suggested that environmental factors and sex hormones play major roles in the etiology of HB (4). Estrogen maintains the function of sex organs and regulates metabolism in humans (5). Environmental sources of estrogen include pesticides, plastics, detergents, combustion products, as well as industrial and agricultural waste products (6). Once estrogen enters the body, it can affect the endocrine system and promote the growth of hormonesensitive tumors. Correlations between estrogen and tumorigenesis have been investigated in various studies (7-10). It has been demonstrated that estrogen regulates the expression of specific biomarkers in breast cancer (11). Another study has suggested that estrogen promotes angiogenesis and, consequently, the proliferation of hemangiomas in children (12). However, there is little known about the role of estrogen in hepatoblastoma.

Telomerase is a type of reverse transcriptase consisting of a ribonucleoprotein complex with a RNA template and various catalytic and regulatory subunits. It is expressed in $98 \%$ of immortalized cell lines and $>90 \%$ of malignant tumors (13). Telomerase activity is principally responsible for the infinite proliferative capacity of tumors (14).

This study investigated the effects of physiological and environmental estrogen on HB by treating human hepatoblastoma HepG2 cells with $17 \beta$-estradiol (E2) and bisphenol A (BPA), and then evaluating cell proliferation, apoptosis, and telomerase activity. The mechanism of action of these hormones was examined using anti-estrogen ICI 182,780 (hereinafter $\mathrm{ICl}$ ).

\section{Material and Methods}

\section{Cells and reagents}

The HepG2 cell line was provided by the Medical School of Zhengzhou University. Phenol red-free Roswell

Correspondence: G.J. Hou: <hougj08@163.com>. 
Park Memorial Institute (RPMI) 1640 medium and fetal bovine serum (FBS) were obtained from Gibco (USA). ICI was purchased from Santa Cruz Biotechnology Co., Ltd. (China). E2 was from IBL International (Germany). The cell counting kit (CCK)-8 was from Dojindo (Japan). Dimethyl sulfoxide (DMSO) was obtained from Zhengzhou Chengxiang Chemical Technology Ltd. (China). The reverse transcription kit was purchased from Invitrogen (USA). SYBR Green supermix was from Toyobo (Japan), and the Telo TAGGG Telomerase PCR enzyme-linked immunosorbent assay (ELISA) kit was from Nanjing KeyGEN Biotech Co., Ltd. (China). Penicillin and streptomycin were purchased from Beijing BioDee Biotechnology Co. Ltd (China).

\section{Primer and probe design}

Primers and probes were synthesized by Invitrogen. The sequence of forward primer TS was $5^{\prime}$-AATCCG TCGAGCAGAGTT-3', which was labeled with biotin at the $5^{\prime}$-end. The sequence of reverse primer $C X$ was 5'-CCCTTACCCTTACCCTTACCCTTA-3'. The probe sequence was $5^{\prime}$-CCCTAACCCTAACCCTAA-3' labeled with digoxin at the $5^{\prime}$-end.

\section{Cell culture}

HepG2 cells were cultured in RPMI 1640 medium containing $10 \%$ FBS, $100 \mathrm{U} / \mathrm{mL}$ penicillin, and $100 \mathrm{U} / \mathrm{mL}$ streptomycin at $37^{\circ} \mathrm{C}$ with $5 \% \mathrm{CO}_{2}$ and saturated humidity. After the cells had attached to the culture dish, the medium was replaced with phenol red-free RPMI 1640 medium, and the cells were cultured for $24 \mathrm{~h}$. The cells were examined daily by phase contrast microscopy.

\section{Reagent preparation and determination of effective doses}

$\mathrm{BPA}, \mathrm{E} 2$, and $\mathrm{ICl}$ were dissolved in DMSO and stored at $-20^{\circ} \mathrm{C}$. Working solutions were prepared by diluting the stock solutions in phenol red-free RPMI 1640 medium. HepG2 cells were resuspended at $1 \times 10^{6}$ cells $/ \mathrm{mL}$ and seeded in a 96-well plate with $200 \mu \mathrm{L}$ each well. After adherence, the culture medium was removed, and cells were washed twice with phosphate-buffered saline (PBS) before BPA or E2 was added at various concentrations $\left(0,2 \times 10^{-5}, 2 \times 10^{-4}, 2 \times 10^{-3}, 2 \times 10^{-2}, 2 \times 10^{-1}, 2 \times 10^{0}\right.$, $2 \times 10^{1}$, and $2 \times 10^{2} \mu \mathrm{g} / \mathrm{mL}$ BPA; $0,1 \times 10^{-5}, 1 \times 10^{-4}$, $1 \times 10^{-3}, \quad 1 \times 10^{-2}, \quad 1 \times 10^{-1}, \quad 1 \times 10^{0}, \quad 1 \times 10^{1}, \quad$ and $1 \times 10^{2} \mathrm{ng} / \mathrm{mL}$ E2). Normal liver cells were similarly treated with the various concentrations of BPA or E2. $\mathrm{ICl}$ was used at $1 \times 10^{-6} \mathrm{M}$ according to a previous report (15).

\section{Treatment groups}

Cells were divided into 6 treatment groups as follows: control (DMSO only), BPA, E2, ICl, BPA+ICl, and $\mathrm{E} 2+\mathrm{ICl}$. The volume of DMSO in each group was $<0.1 \%$ of the total volume.

\section{Analysis of cell proliferation}

Cells were seeded at $1 \times 10^{5}$ cells/well in a 96 -well plate. After adherence, the culture medium was removed, and cells were washed twice with PBS. CCK-8 solution $(10 \mu \mathrm{L})$ was added to each well at $0,24,48,72,96$, and $120 \mathrm{~h}$, and the cells were cultured for an additional $3 \mathrm{~h}$ before the absorbance at $450 \mathrm{~nm}\left(\mathrm{~A}_{450 \mathrm{~nm}}\right)$ was determined using a microplate reader (Bio-Rad). A growth curve was generated from the measured values.

\section{Examination of the cell cycle distribution and apoptosis}

Cells were collected at the logarithmic growth phase and seeded at $3 \times 10^{5}$ cells $/ 25 \mathrm{~mL}$ culture flask. After $24 \mathrm{~h}$, the cells were washed twice with PBS and subjected to the various treatments. After $48 \mathrm{~h}, 1-5 \times 10^{6}$ cells were collected by trypsinization and centrifuged at $12,000 \mathrm{~g}$ for $5 \mathrm{~min}$ at $4^{\circ} \mathrm{C}$. The cells were then repeatedly washed with PBS and fixed in pre-cooled $70 \%$ alcohol at $-20^{\circ} \mathrm{C}$ overnight. After washing with PBS, the cells were treated with RNase A $(10 \mu \mathrm{L}$ of a $20 \mu \mathrm{g} / \mathrm{mL}$ stock solution in $500 \mu \mathrm{L}$ PBS) for $30 \mathrm{~min}$ at $37^{\circ} \mathrm{C}$, followed by centrifugation at $8,000 \mathrm{~g}$ for $5 \mathrm{~min}$ at $4^{\circ} \mathrm{C}$. The cells were then incubated with $10 \mu \mathrm{L}$ of a propidium iodide solution $(50 \mu \mathrm{g} / \mathrm{mL}$ in $500 \mu \mathrm{L}$ PBS) for $30 \mathrm{~min}$ at room temperature in the dark. Cell cycle and apoptosis analyses were carried out by flow cytometry (BD Biosciences, USA) using CellQuest software (BD Biosciences, USA). A total of 10,000 cells was used to analyze and the cell cycle distribution with FlowJo software (USA).

\section{Analysis of telomerase activity}

A PCR-telomeric repeat amplification protocol (TRAP)-ELISA kit $(16,17)$ was used to determine the telomerase activity of HepG2 cells according to the manufacturer's instructions. Briefly, the cells were collected at each time point and washed twice with normal saline. A lysis solution $(200 \mu \mathrm{L})$ was then added to dissolve the cells. After $30 \mathrm{~min}$ of incubation, the cells were centrifuged at $12,000 \mathrm{~g}$ for $20 \mathrm{~min}$ at $4^{\circ} \mathrm{C}$, and the supernatant was stored at $-80^{\circ} \mathrm{C}$ until use. Two microliters of telomerase extraction solution incubated at $65^{\circ} \mathrm{C}$ for $10 \mathrm{~min}$ was used for the negative control. The TRAP reaction was carried out in a $50 \mu \mathrm{L}$ volume including $2 \times$ substrate buffer $(25 \mu \mathrm{L})$, TS and CX primers ( $2 \mu \mathrm{L}$ or $100 \mathrm{ng}$ each) $2 U$ Taq enzyme $(1 \mu \mathrm{L})$, TRAP template $(1 \mu \mathrm{L})$, and sterile diethylpyrocarbonate water. Sterile paraffin oil $(40 \mu \mathrm{L})$ was used to overlay the reaction solution. Telomeric repeat sequences were synthesized by telomerase at $25^{\circ} \mathrm{C}$ for $30 \mathrm{~min}$, and then the enzyme was inactivated at $94^{\circ} \mathrm{C}$ for $5 \mathrm{~min}$. The PCR conditions were as follows: 30 cycles of $94^{\circ} \mathrm{C}$ for $30 \mathrm{~s}, 50^{\circ} \mathrm{C}$ for $30 \mathrm{~s}$, and $72^{\circ} \mathrm{C}$ for $90 \mathrm{~s}$, followed by final extension at $72^{\circ} \mathrm{C}$ for $10 \mathrm{~min}$. To detect telomerase activity, a polyvinyl chloride panel was coated with 1:50 biotin-streptavidin (50 $\mu \mathrm{L}$ per well) overnight at $4^{\circ} \mathrm{C}$. The following day, the panel was 
washed four times with cleaning solution (10 mM Hepes$\mathrm{KOH}, 1.5 \mathrm{mM} \mathrm{MgCl}_{2}, 10 \mathrm{mM} \mathrm{KCl}$, and $1 \mathrm{mM}$ DTT). PCR product $(5 \mu \mathrm{L})$ was mixed with $20 \mu \mathrm{L}$ denaturation solution $(0.5 \% \mathrm{NaOH})$, followed by incubation for $10 \mathrm{~min}$ at room temperature and then addition of $225 \mu \mathrm{L}$ hybridization solution. A total of $100 \mu \mathrm{L}$ of the mixture was transferred to the panel, and hybridization was carried out at $37^{\circ} \mathrm{C}$ for $3 \mathrm{~h}$. After three washes with washing buffer, $100 \mu \mathrm{L}$ peroxidaseconjugated anti-digoxin antibody was added to the panel, followed by incubation for $30 \mathrm{~min}$ at $37^{\circ} \mathrm{C}$. After five washes with washing buffer, $100 \mu \mathrm{L}$ substrate buffer (containing $3,3^{\prime}, 5,5^{\prime}$-tetramethylbenzidine) was added to the panel. Color development was allowed to proceed for 10-15 min. The reaction was terminated by addition of $2 \mathrm{M}$ sulfuric acid. Telomerase activity was determined by measuring the $\mathrm{A}_{450 \mathrm{~nm}}$ (reference wavelength: $630 \mathrm{~nm}$ ) on a microplate reader. Negative and positive control measurements corresponded to $A_{450 n m}<0.2$ and $A_{450 n m}>1.0$, respectively.

\section{Statistical analysis}

Data are reported as means \pm SD. Comparisons between groups were performed by one-way analysis of variance. MATLAB software (MathWorks, USA) was used for all statistical analyses. $\mathrm{P}<0.05$ was considered to be statistically significant.

\section{Results}

\section{E2 and BPA stimulate HepG2 cell proliferation}

After $120 \mathrm{~h}$ of treatment, the effective concentrations of E2 and BPA to stimulate HepG2 cell proliferation were $2 \mu \mathrm{g} / \mathrm{mL}$ and $10 \mathrm{ng} / \mathrm{mL}$, respectively (Figure 1). For normal liver cells, both BPA and E2 had inhibitory effects on their growth (Figure 2). At various time points, BPA, E2, $\mathrm{BPA}+\mathrm{ICl}$, and $\mathrm{E} 2+\mathrm{ICl}$ groups had the highest proliferation rates, whereas $\mathrm{ICl}$ alone had little effect on cell growth (Figure 3 and Table 1). Cell numbers in the BPA group at 48,72 , and $96 \mathrm{~h}$ were significantly higher $(P<0.01$ or $\mathrm{P}<0.05)$ and those in the $\mathrm{E} 2$ group were higher at 24, 48, and $72 \mathrm{~h}(\mathrm{P}<0.01)$ compared with control cells. Compared with the $\mathrm{ICl}$ group, cell numbers were higher in the $\mathrm{BPA}+\mathrm{ICl}$ group at 48,96 , and $120 \mathrm{~h}(\mathrm{P}<0.01$ or $\mathrm{P}<0.05)$ and in the $\mathrm{E} 2+\mathrm{ICl}$ group at $48,72,96$, and $120 \mathrm{~h}$ $(P<0.01)$. These results indicate that $E 2$ and BPA induce the proliferation of HepG2 cells.

\section{Cell cycle regulation is affected by E2 and BPA}

The proportions of cells in the various cell cycle phases were obviously different in E2- and BPA-treated cells and control cells $(P<0.05$; Figure 4). Similarly, there were significant differences in the cell cycle distributions of BPA $+\mathrm{ICl}$ and $\mathrm{E} 2+\mathrm{ICl}$ groups compared with the $\mathrm{ICl}$ group $(P<0.05)$. No statistical difference was found between BPA and $\mathrm{BPA}+\mathrm{ICl}$ groups or between $\mathrm{E} 2$ and $\mathrm{E} 2+\mathrm{ICl}$ groups $(P>0.05)$. These results indicate that $E 2$ and BPA stimulate HepG2 cell proliferation by altering the cell cycle.
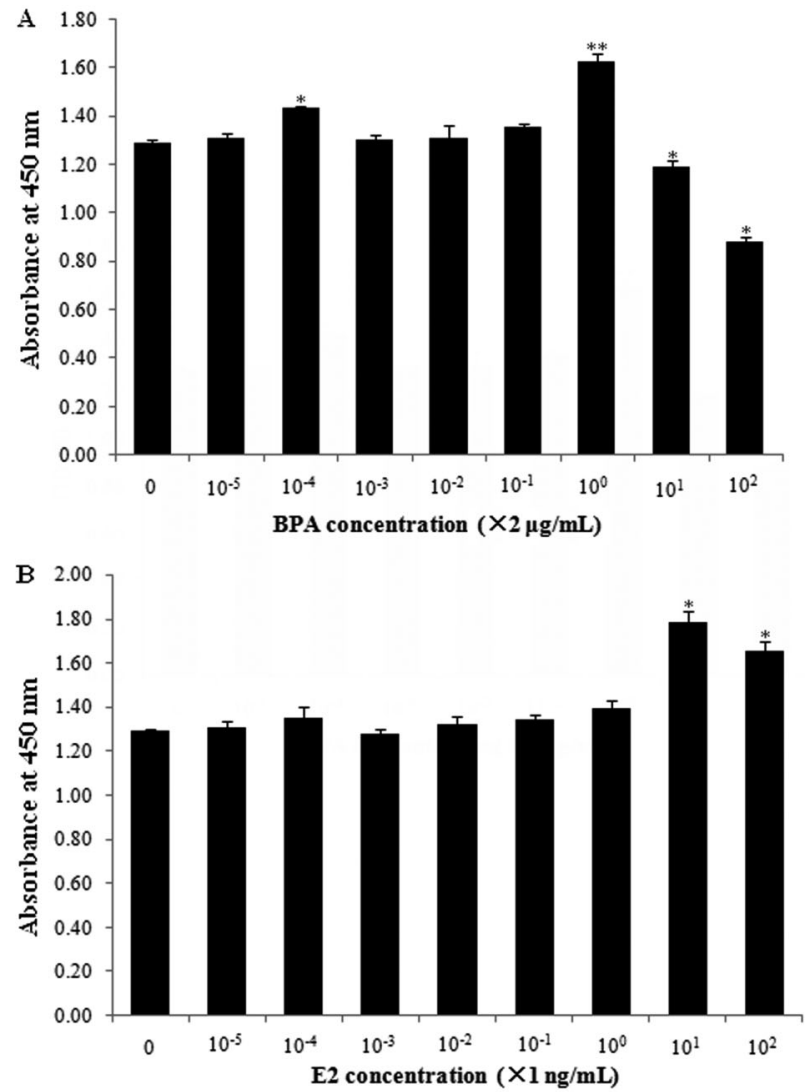

Figure 1. Screening for optimal concentrations of bisphenol A (BPA) and estradiol (E2) to stimulate HepG2 cell proliferation. Data are reported as means $\pm S D$. ${ }^{*} P<0.05,{ }^{* *} P<0.01$ compared to no treatment (one-way ANOVA).

\section{E2 and BPA inhibit apoptosis of HepG2 cells}

Flow cytometry showed that the apoptotic index was markedly reduced in cells treated with E2 and BPA compared with the control group $(P<0.05$; Figure 5). Similarly, compared with cells treated with $\mathrm{ICl}$ alone, apoptosis rates were reduced in $\mathrm{BPA}+\mathrm{ICl}$ and $\mathrm{E} 2+\mathrm{ICl}$ groups $(P<0.05)$. Differences between control and $\mathrm{ICl}$ groups, BPA and BPA $+\mathrm{ICl}$ groups, and E2 and E2 $+\mathrm{ICl}$ groups were not statistically significant $(P>0.05)$. These data demonstrate that E2 and BPA inhibit apoptosis of HepG2 cells.

\section{Telomerase activity is induced by E2 and BPA}

Telomerase activity in HepG2 cells was evaluated by a PCR-TRAP-ELISA. Compared with the control group, telomerase activity was enhanced in BPA- and E2-treated cells at 48 and $72 \mathrm{~h}(\mathrm{P}<0.05$; Figure 6$)$. Similarly, compared with the $\mathrm{ICl}$ group, telomerase activity was higher in $\mathrm{BPA}+\mathrm{ICl}$ and $\mathrm{E} 2+\mathrm{ICl}$ groups at 48 and $72 \mathrm{~h}(\mathrm{P}<0.05)$. There were no differences between $\mathrm{ICl}$ and control groups at any time point $(\mathrm{P}>0.05)$. 

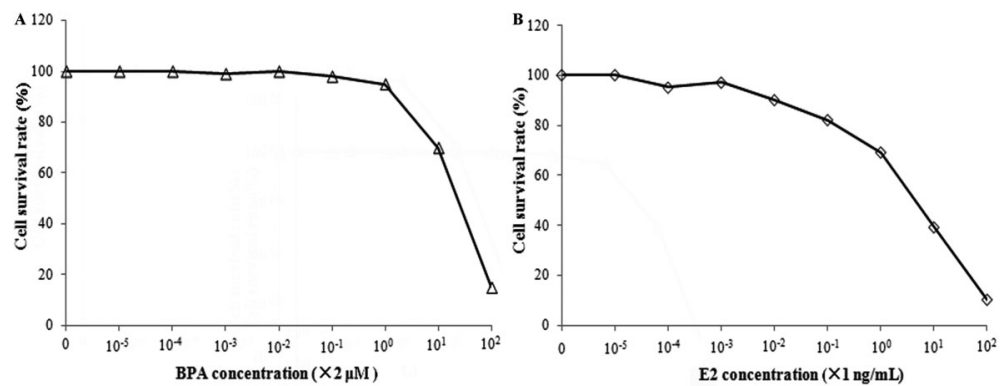

Figure 2. Inhibitory effect of bisphenol A (BPA) and estradiol (E2) on normal liver cell survival. The inhibitory action was stronger with increased dosage of BPA and E2.

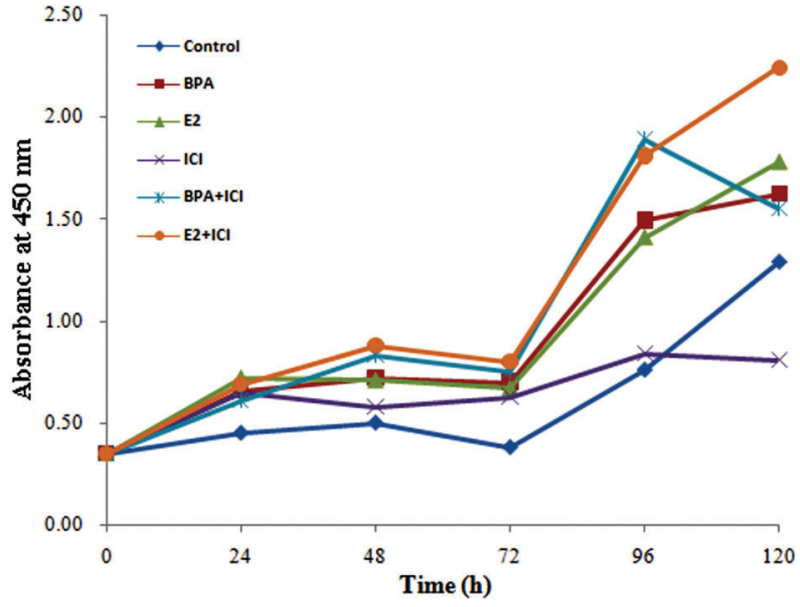

Figure 3. Growth curve of HepG2 cells treated with bisphenol A (BPA) or estradiol (E2) alone or in combination with the antiestrogen ICI 182,780 (ICl).

\section{Discussion}

$\mathrm{HB}$ is the most common type of pediatric liver tumor. It is highly malignant, associated with poor outcomes, even after treatment, and characterized by occult occurrence, vascular enrichment, rapid growth, and early metastasis $(18,19)$. The pathogenesis of $\mathrm{HB}$ remains

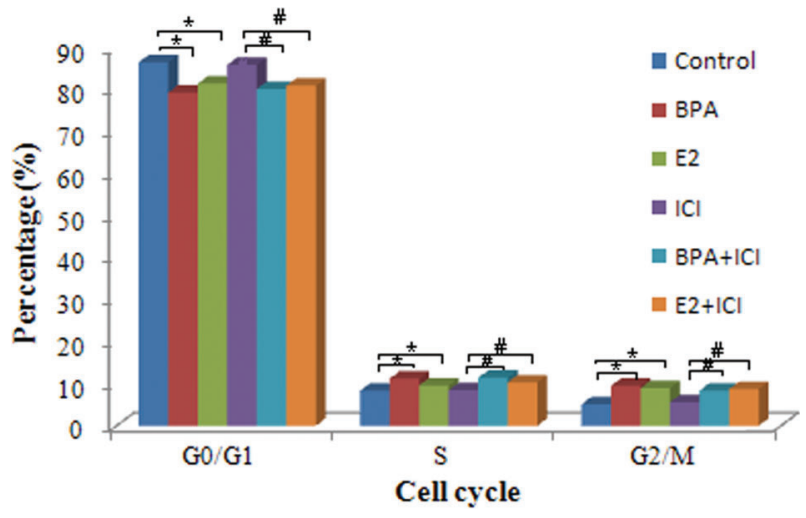

Figure 4. Effect of bisphenol A (BPA) and estradiol (E2) on the HepG2 cell cycle distribution. Data are reported as means \pm SD. ICl: ICI 182,780. *P $<0.05$ compared to control group; ${ }^{*} \mathrm{P}<0.05$ compared to $\mathrm{ICl}$ group (one-way ANOVA).

unclear, but it is thought to arise from mutations and changes in hormone levels caused by environmental factors $(4,20)$. For example, some childhood cases of $\mathrm{HB}$ have been linked to the use of oral contraceptives by the mother (4), suggesting the influence of estrogen. The estrogen antagonist tamoxifen has been shown to stimulate HepG2 cell activity and inhibit apoptosis (21). Furthermore, estrogen antagonists inhibit expression of

Table 1. Effect of bisphenol A (BPA) and estradiol (E2) on HepG2 cell viability.

\begin{tabular}{lcccccc}
\hline Group & \multicolumn{7}{c}{ Absorbance at $450 \mathrm{~nm}$} \\
\cline { 2 - 7 } & \multicolumn{1}{c}{$0 \mathrm{~h}$} & \multicolumn{1}{c}{$24 \mathrm{~h}$} & \multicolumn{1}{c}{$48 \mathrm{~h}$} & \multicolumn{1}{c}{$72 \mathrm{~h}$} & \multicolumn{1}{c}{$96 \mathrm{~h}$} & $120 \mathrm{~h}$ \\
\hline Control & $0.35 \pm 0.01$ & $0.45 \pm 0.05$ & $0.50 \pm 0.05$ & $0.38 \pm 0.10$ & $0.76 \pm 0.15$ & $1.29 \pm 0.17$ \\
$\mathrm{BPA}$ & $0.35 \pm 0.01$ & $0.66 \pm 0.11$ & $0.72 \pm 0.03^{\star *}$ & $0.70 \pm 0.06^{\star *}$ & $1.49 \pm 0.11^{*}$ & $1.62 \pm 0.26$ \\
E2 & $0.35 \pm 0.01$ & $0.72 \pm 0.04^{* *}$ & $0.71 \pm 0.01^{* *}$ & $0.67 \pm 0.08^{* *}$ & $1.41 \pm 0.22$ & $1.78 \pm 0.14$ \\
$\mathrm{ICl}$ & $0.35 \pm 0.01$ & $0.65 \pm 0.10$ & $0.58 \pm 0.05$ & $0.63 \pm 0.11$ & $0.84 \pm 0.25$ & $0.81 \pm 0.21$ \\
$\mathrm{BPA}+\mathrm{ICl}$ & $0.35 \pm 0.01$ & $0.61 \pm 0.08$ & $0.83 \pm 0.02^{\# \#}$ & $0.75 \pm 0.03$ & $1.89 \pm 0.21^{\# \#}$ & $1.55 \pm 0.16^{\#}$ \\
E2+ICl & $0.35 \pm 0.01$ & $0.69 \pm 0.02$ & $0.88 \pm 0.00^{\# \#}$ & $0.80 \pm 0.05^{\# \#}$ & $1.81 \pm 0.30^{\# \#}$ & $2.24 \pm 0.24^{\# \#}$ \\
\hline
\end{tabular}

Data are reported as means $\pm \mathrm{SD}$. ${ }^{*} \mathrm{P}<0.05,{ }^{\text {** }} \mathrm{P}<0.01$ compared to control group; ${ }^{\#} \mathrm{P}<0.05,{ }^{\# \#} \mathrm{P}<0.01$ compared to ICl (ICl 182,780) group (one-way ANOVA). 


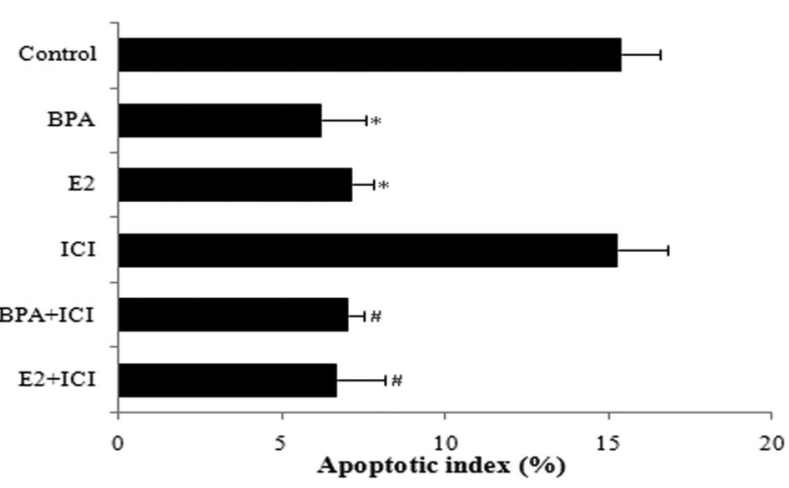

Figure 5. Apoptotic index of HepG2 cells treated with bisphenol A (BPA) or estradiol (E2) alone or in combination with the antiestrogen ICl 182,780 (ICl) for $48 \mathrm{~h}$. Data are reported as means $\pm \mathrm{SD}$. ${ }^{*} \mathrm{P}<0.05$ compared to control group; ${ }^{\#} \mathrm{P}<0.05$ compared to ICl group (one-way ANOVA).

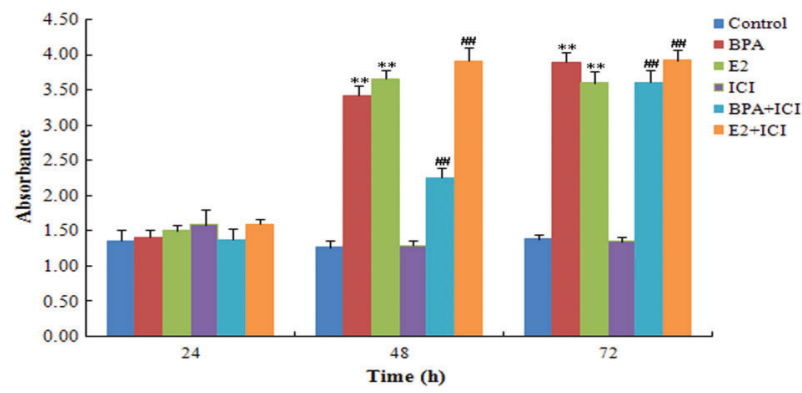

Figure 6. Effect of bisphenol A (BPA) and estradiol (E2) on telomerase activity in HepG2 cells. Cells were treated with BPA or E2 alone or in combination with the anti-estrogen ICI 182,780 (ICI). Telomerase activity was assessed by the PCR-telomeric repeat amplification protocol (TRAP). Data are reported as means \pm SD. ${ }^{* *} P<0.01$ compared to control group; ${ }^{\# \#} P<0.01$ compared to $\mathrm{ICl}$ group (one-way ANOVA test).

\section{References}

1. Zhang SC, Wang WL, Cai WS, Jiang KL, Yuan ZW. Engineered measles virus Edmonston strain used as a novel oncolytic viral system against human hepatoblastoma. BMC Cancer 2012; 12: 427, doi: 10.1186/1471-2407-12-427.

2. Miller RW, Young JLJr, Novakovic B. Childhood cancer. Cancer 1995; 75 (1 Suppl): 395-405.

3. Zhang Q, Ming J, Zhang S, Guo D, Quu X. A rare case of adult hepatoblastoma with neuroendocrine differentiation misdiagnosed as neuroendocrine tumor. Int J Clin Exp Pathol 2013; 6: 308-313.

4. Pilotti G, Bosco M, Leo D, Ricci C, Suria G. [Hepatoblastoma in an infant after estroprogestational intake by the mother during pregnancy]. Pediatr Med Chir 1983; 6: 323-325.

5. Faulds MH, Zhao C, Dahlman-Wright K, Gustafsson JA. The diversity of sex steroid action: regulation of metabolism by estrogen signaling. J Endocrinol 2012; 212: 3-12, doi: 10.1530/JOE-11-0044. the estrogen receptor and HepG2 cell proliferation in vitro in time- and concentration-dependent manners (22). Consistent with these previous findings, the present results showed that $\mathrm{E} 2$ and the environmental estrogen BPA promote HepG2 cell proliferation, which may be due to inhibition of apoptosis because treatment with these agents had no effect on the cell cycle distribution. Cotreatment with $\mathrm{ICl}$ did not alter the effects of E2 or BPA, indicating that these agents act via a non-estrogen receptor-dependent pathway in accordance with the known mechanism of estrogen receptor signaling (21).

The role of telomerase in tumor malignancy has been highlighted by many studies. According to a previous report, the hyperproliferation of tumor cells in $90 \%$ of human malignancies is linked to inappropriate telomerase activity (23). A study of 100 immortalized cell lines derived from 18 types of tumor tissues demonstrated that 98 cell lines had abnormally high telomerase activity by TRAP in contrast to cells from non-cancerous tissue that were negative for telomerase activity (24). Here, we showed that E2 and BPA stimulate telomerase activity in HepG2 cells. Therefore, inhibition of apoptosis by these two agents may be achieved by stimulation of telomerase activity, which suppresses telomere shortening, chromosomal damage, and ultimately apoptosis (24). This finding is substantiated by the observation that tamoxifen induces apoptosis of HepG2 cells by suppression of telomerase function (21). Taken together, these results indicate that therapeutic agents targeting telomerase may be effective for the treatment of $\mathrm{HB}$. Moreover, our findings provide an insight into the mechanisms underlying the tumorigenic effects of physiological and environmental estrogens.

\section{Acknowledgments}

We thank the Medical School of Zhengzhou University for providing the HepG2 cells.

6. Nilsson EE, Skinner MK. Environmentally induced epigenetic transgenerational inheritance of disease susceptibility. Transl Res 2015; 165: 12-17, doi: 10.1016/j.trsl.2014. 02.003 .

7. Mathieu D, Zafrani ES, Anglade MC, Dhumeaux D. Association of focal nodular hyperplasia and hepatic hemangioma. Gastroenterology 1989; 97: 154-157.

8. Saegusa T, Ito K, Oba N, Matsuda M, Kojima K, Tohyama K, et al. Enlargement of multiple cavernous hemangioma of the liver in association with pregnancy. Intern Med 1995; 34 : 207-211, doi: 10.2169/internalmedicine.34.207.

9. Glinkova V, Shevah O, Boaz M, Levine A, Shirin H. Hepatic haemangiomas: possible association with female sex hormones. Gut 2004; 53: 1352-1355, doi: 10.1136/gut.2003. 038646.

10. Aktas B, Muller V, Tewes M, Zeitz J, Kasimir-Bauer S, Loehberg CR, et al. Comparison of estrogen and 
progesterone receptor status of circulating tumor cells and the primary tumor in metastatic breast cancer patients. Gynecol Oncol 2011; 122: 356-360, doi: 10.1016/j.ygyno.2011.04.039.

11. Bartlett JM, Brookes CL, Robson T, van de Velde CJ, Billingham LJ, Campbell FM, et al. Estrogen receptor and progesterone receptor as predictive biomarkers of response to endocrine therapy: a prospectively powered pathology study in the Tamoxifen and Exemestane Adjuvant Multinational trial. J Clin Oncol 2011; 29: 1531-1538, doi: 10.1200/ JCO.2010.30.3677.

12. Verma K, Tran D, Bryan B, Mitchell D. Meta-analysis of infantile hemangioma endothelial cell microarray expression data reveals significant aberrations of gene networks involved in cell adhesion and extracellular matrix composition. Angiology 2013; 1: 2.

13. Kim NW, Piatyszek MA, Prowse KR, Harley CB, West MD, Ho PL, et al. Specific association of human telomerase activity with immortal cells and cancer. Science 1994; 266 : 2011-2015, doi: 10.1126/science.7605428.

14. Holt SE, Wright WE, Shay JW. Regulation of telomerase activity in immortal cell lines. Mol Cell Biol 1996; 16: 2932-2939.

15. Zhu H, Xiao X, Zheng J, Zheng S, Dong K, Yu Y. Growthpromoting effect of bisphenol $A$ on neuroblastoma in vitro and in vivo. J Pediatr Surg 2009; 44: 672-680, doi: 10.1016/ j.jpedsurg.2008.10.067.

16. Hoos A, Hepp HH, Kaul S, Ahlert T, Bastert G, Wallwiener D. Telomerase activity correlates with tumor aggressiveness and reflects therapy effect in breast cancer. Int $J$ Cancer 1998; 79: 8-12.

17. Wu YY, Hruszkewycz AM, Delgado RM, Yang A, Vortmeyer $A O$, Moon $Y W$, et al. Limitations on the quantitative determination of telomerase activity by the electrophoretic and ELISA based TRAP assays. Clin Chim Acta 2000; 293: 199-212, doi: 10.1016/S0009-8981(99)00238-7.

18. Haas JE, Muczynski KA, Krailo M, Ablin A, Land V, Vietti TJ, et al. Histopathology and prognosis in childhood hepatoblastoma and hepatocarcinoma. Cancer 1989; 64: 1082-1095.

19. Karski EE, Dvorak CC, Leung W, Miller W, Shaw PJ, Qayed $M$, et al. Treatment of hepatoblastoma with high-dose chemotherapy and stem cell rescue: the pediatric blood and marrow transplant consortium experience and review of the literature. J Pediatr Hematol Oncol 2014; 36: 362-368, doi: 10.1097/MPH.0000000000000130.

20. Nielsen J, Jensen RB, Juul A. Increased sex hormonebinding globulin levels in children and adolescents with thyrotoxicosis. Horm Res Paediatr 2013; 79: 157-161, doi: 10.1159/000348837.

21. Brandt S, Heller H, Schuster KD, Grote J. Tamoxifen induces suppression of cell viability and apoptosis in the human hepatoblastoma cell line HepG2 via down-regulation of telomerase activity. Liver Int 2004; 24: 46-54, doi: 10.1111/j.1478-3231.2004.00887.x.

22. Jaber BM, Mukopadhyay R, Smith CL. Estrogen receptoralpha interaction with the CREB binding protein coactivator is regulated by the cellular environment. $J$ Mol Endocrinol 2004; 32: 307-323.

23. Skordalakes $\mathrm{E}$. Telomerase structure paves the way for new cancer therapies. Future Oncol 2009; 5: 163-167, doi: 10.2217/ 14796694.5.2.163.

24. Zhang X, Mar V, Zhou W, Harrington L, Robinson MO. Telomere shortening and apoptosis in telomerase-inhibited human tumor cells. Genes Dev 1999; 13: 2388-2399, doi: 10.1101/gad.13.18.2388. 